\title{
Coordinated variation between veins and stomata in cotton and its relationship with water-use efficiency under drought stress
}

\author{
Z.Y. LEI, J.M. HAN, X.P YI, W.F. ZHANG, and Y.L. ZHANG ${ }^{+}$ \\ Key Laboratory of Oasis Eco-agriculture, Xinjiang Production and Construction Group, Agricultural College, \\ Shihezi University, Shihezi, Xinjiang 832003, China
}

\begin{abstract}
Drought stress causes changes in vein and stomatal density. The objectives of this study were to determine (1) if the changes in vein and stomatal density are coordinated in cotton (Gossypium hirsutum L.) and (2) how these changes affect water-use efficiency (WUE). The results showed significant positive correlations between vein density and stomatal density when cotton was grown under different degrees of drought stress. WUE was significantly positively correlated with the densities of both veins and stomata. Stomatal pore area and stomatal density on the abaxial leaf side, but not the adaxial side, were significantly correlated with WUE, stomatal conductance, leaf net photosynthetic rate, and transpiration rate. In conclusion, coordinated changes in vein and stomatal density improve the WUE of cotton under drought stress. The abaxial leaf side plays a more important role than the adaxial side in WUE and gas exchange.
\end{abstract}

Additional key words: major leaf veins; maximum stomatal conductance; minor leaf veins; photosynthesis; stomata size.

\section{Introduction}

Water transport is a continuous process in plants (Philip 2003). In terrestrial plants, water is taken from soil by roots and then transported to the petiole through the stem. The water then moves from veins into mesophyll cells and evaporation sites near the stomatal cavity. Water near the stomatal pores is rapidly lost to the atmosphere. Thus, at the leaf level, veins and stomata are important structures determining plant water use (Sack and Frole 2006).

Veins are a conduit system for water. The density of veins determines their capacity and efficiency to supply water to leaf cells (Brodribb et al. 2007, Boyce et al. 2009, McKown et al. 2010, Brodribb and Jordan 2011). Vein characteristics directly affect plant water supply, which in turn is closely related to physiological activity. Maximum hydraulic conductance and maximum photosynthetic rate are both closely related to leaf vein density (Sack and Frole 2006, Brodribb et al. 2007).

Water transport and $\mathrm{CO}_{2}$ diffusion inside leaves are two important functional traits determining $\mathrm{CO}_{2}$ assimilation efficiency (Sack and Holbrook 2006). As channels for gas exchange between plants and the atmosphere, stomata are another important structure affecting the leaf water balance (Küppers 1984, Meinzer et al. 1991, Brodribb and Feild 2000, Brodribb and Jordan 2011). Leaf transpiration is directly related to stomatal density and stomatal size (Franks et al. 2009a, Zhang et al. 2012).

Studies have shown coordinated development between vein density and stomatal density in the evergreen Nothofagus cunninghamii (Hook.) Oerst (Brodribb and Jordan 2011) and in 17 species of Paphiopedilum (Zhang et al. 2012). In leaves of the woody angiosperm Toona ciliata M. Roem, vein density and stomatal density are regulated by leaf expansion so that leaf hydraulic conductance and stomatal conductance $\left(g_{\mathrm{s}}\right)$ remain proportional (Carins et al. 2012). Several recent studies have examined the effects of environment on vein and stomatal density. One of those studies reported that tobacco (Nicotiana tabacum L.) responds to differences in day/night temperature by adjusting the density of minor veins and stomata density in a correlated manner ( $\mathrm{Hu}$ et al.

Received 19 July 2017, accepted 1 January 2018, published as online-first 27 June 2018.

${ }^{+}$Corresponding author; e-mail: zhangyali cn@foxmail.com; zhangyali shzu@,163.com

Abbreviations: $C_{\mathrm{i}}$ - intercellular $\mathrm{CO}_{2}$ concentration; $E$ - transpiration rate; $g_{\mathrm{s}}$ - stomatal conductance; MS - mild drought stress; MDS - moderate drought stress; LMA - leaf dry mass per area; $P_{\mathrm{N}}$ - net photosynthetic rate; WUE - water-use efficiency; $\mathrm{WUE}_{\mathrm{i}}$ - intrinsic water-use efficiency; WW - well-watered treatment.

Acknowledgements: This study was financially supported by the National Natural Science Foundation of China (Grant No. U1303183), by the Fok Ying-Tong Education Foundation (Grant No.141023). 
2014). A similar correlation between minor vein and stomatal density was observed when peanut (Arachis hypogaea L.) was grown under varying light conditions (Zhao et al. 2017). These results suggest coordination between leaf water supply and demand. Relatively little is known about coordination between stomatal density and vein density under drought stress.

Drought is a primary factor limiting crop productivity. High WUE is a major prerequisite for plants to survive under hot and dry conditions (Costa et al. 2007, Morison et al. 2008). Plants improve WUE by (1) concentrating $\mathrm{CO}_{2}$, (2) increasing the conductance of $\mathrm{CO}_{2}$ through the mesophyll, and (3) increasing Rubisco activity (Parry et al. 2005, Flexas et al. 2010, 2013; Gago et al. 2014). A previous study reported that some soybean (Glycine max L. Merrill) cultivars exposed to supplemental UV-B radiation increased WUE by altering stomatal development and function (Gitz et al. 2005). Franks et al. (2015) studied Arabidopsis mutants which exhibited differences in stomatal density due to overexpression of epidermal patterning factor. The authors reported that reduced

\section{Materials and methods}

Experimental design: The field experiment was carried out at an agricultural experimental field near Shihezi University, Xinjiang, China $\left(45^{\circ} 19^{\prime} \mathrm{N}, 8^{\circ} 03^{\prime} \mathrm{E}\right)$. The soil texture at the site is clay loam.

The experiment consisted of a completely randomized block design with three treatments: (1) well-watered (WW, the total irrigation amount between 8 June and 20 August was $4500 \mathrm{~m}^{3} \mathrm{ha}^{-1}$ ); (2) mild drought stress (MS, 60\% of WW, $2700 \mathrm{~m}^{3} \mathrm{ha}^{-1}$ ); and (3) moderate drought stress (MDS, $20 \%$ of $\mathrm{WW}, 900 \mathrm{~m}^{3} \mathrm{ha}^{-1}$ ). The total irrigation amount in WW was the same as that used by local farmers. Each treatment was replicated three times.

Upland cotton (Gossypium hirsutum L., cv. Xinluzao 45) was sown in the plots on 18 April 2016. The plant density was $1.8 \times 10^{5}$ plants $\mathrm{ha}^{-1}$. All of the plots were irrigated with the same amount of water two days after sowing in order to promote germination. The treatments were imposed $50 \mathrm{~d}$ after sowing ( 8 June). The plots were watered ten times (at 6-10-d intervals) between 8 June and 20 August. The irrigation amounts per application were 450, 270, and $90 \mathrm{~m}^{3} \mathrm{ha}^{-1}$ in the WW, MS, and MDS treatments, respectively. The measurements described in the sections below were performed between 15 July and 30 July (37-52 d after the treatments were imposed).

The plots $\left(31.5 \mathrm{~m}^{2}\right)$ were fertilized before planting with $156 \mathrm{~kg}(\mathrm{~N}) \mathrm{ha}^{-1}$ (urea) and $225 \mathrm{~kg}(\mathrm{P}) \mathrm{ha}^{-1}\left(\mathrm{KH}_{2} \mathrm{PO}_{4}\right)$. Additional fertilizer $\left[520 \mathrm{~kg}(\mathrm{~N}) \mathrm{ha}^{-1}\right.$ and $158 \mathrm{~kg}(\mathrm{P}) \mathrm{ha}^{-1}$ ] was applied to the plots during the growing season via drip irrigation.

Water potential: A pressure chamber (SKPM 1400; Skye Instruments, Llandrindod Wells, UK) was used to measure pre-dawn leaf water potential. After excising the leaves stomatal density increased both instantaneous and longterm WUE. Yoo et al. (2010) reported that the WUE of Arabidopsis was regulated by transcription factor $G T-2$ Like 1, which modulated abaxial stomatal density via transgression of stomatal density and distribution. There are some differences between adaxial and abaxial $g_{\mathrm{s}}$. Under most conditions, including drought, stomatal resistance is considerably greater on the abaxial leaf side than that on the adaxial side (Sharpe 1973).

Cotton (Gossypium hirsutum L) is a common cash crop in arid and semiarid regions of Central Asia. Drought stress can limit cotton yield in those regions. Yields could be increased and irrigation water saved if the WUE of cotton was improved. The objective of this field experiment was to test the following hypotheses: (1) water stress induces coordinated changes in the density of veins and stomata in cotton; (2) the coordinated changes in vein and stomatal density improve WUE; (3) the abaxial leaf side plays a more important role than the adaxial side on WUE and gas exchange.

from the plants, the petioles were immediately sealed in a compression gasket with the cut surface exposed and the leaf blade inside the pressure chamber. The pressure inside the chamber was slowly increased with $\mathrm{N}_{2}$ gas until sap appeared at the cut surface of the petiole.

Gas exchange and WUE: Leaf gas exchange was measured using an open infrared gas-exchange analyzer system (LI-6400; LI-COR Inc., Lincoln, USA) that was equipped with a leaf LED chamber (6400-02B LED). The measurements were made between 11:00 and 14:00 $\mathrm{h}$ under light-saturating conditions (PPFD; 1,800 $\mu \mathrm{mol} \mathrm{m} \mathrm{m}^{-2} \mathrm{~s}^{-1}$ ). The temperature was $28^{\circ} \mathrm{C}$. The measurements were made on one young, fully expanded leaf that was randomly selected in each plot. The leaf chamber was attached to the same portion of each leaf, and the leaf position was not modified. The WUE was calculated by dividing leaf net photosynthetic rate $\left(P_{\mathrm{N}}\right)$ by transpiration rate $(E)$. Intrinsic WUE $\left(\mathrm{WUE}_{\mathrm{i}}\right.$ ) was calculated as $P_{\mathrm{N}} / g_{\mathrm{s}}$.

Leaf dimensions: One leaf was collected from each plot. The area of the leaves was measured with an LI-3000 leaf area meter (LI-COR Inc., Lincoln, USA). The leaf samples were then fixed by vacuum infiltration in $4 \%$ glutaraldehyde and $3 \%$ paraformaldehyde in $0.1 \mathrm{mM}$ phosphate buffer ( $\mathrm{pH}$ 7.2). The leaf samples were then fixed again in $1 \%$ osmium tetroxide overnight, dehydrated in a graded series of acetone solutions, and then embedded in Spurr's resin (or LR White). An ultramicrotome (Leica Ultracut, Wetzlar, Germany) was used to make cut thin (40-nm) sections. The sections were stained with toluidine blue and observed under an electron microscope (JEM1230, JEOL, Tokyo, Japan). Electron micrographs were taken with a 
digital camera (BH-2, Olympus, Tokyo, Japan) at magnifications of $10 \times$ and $40 \times$. Leaf thickness and the distance from the stomata to the nearest vein were determined using ImageJ software.

Ten discs $\left(1.56 \mathrm{~cm}^{2}\right)$ were excised from each leaf, dried at $60^{\circ} \mathrm{C}$ for at least $48 \mathrm{~h}$, and then weighed to determine leaf dry mass per unit leaf area (LMA). Leaf density was calculated by dividing the leaf mass by its volume.

Vein density: In this paper, the term 'major veins' refers to veins which extend from the petiole. The term 'minor veins' refers to all but the major veins. The length of the major veins was measured with a ruler. Major vein density was calculated by dividing the total length of the major veins by the leaf area.

To measure minor veins, leaf sections $(5 \times 5 \mathrm{~mm})$ were excised from the middle of the leaves. The sections were soaked in $80 \%$ alcohol solutions at $65^{\circ} \mathrm{C}$ for about $1.5 \mathrm{~h}$. The alcohol solution was then replaced with $10 \%$ sodium hydroxide solution at $65^{\circ} \mathrm{C}$ for $3 \mathrm{~h}$ and then bleached. The samples were washed with water and then dyed with safranin. The samples were decolorized with a gradient of alcohol. The leaf samples were photographed with a light microscope ( $\mathrm{BH}-2$, Olympus, Tokyo, Japan). The lengths of the minor veins and the area of each leaf section were measured using ImageJ software. Minor vein density was calculated by dividing minor vein length by the area of the leaf section.

Stomata measurements: Leaf sections $(5 \times 8 \mathrm{~mm})$ were excised from the leaves and then fixed in FAA $(50 \%$ alcohol solution, 5\% formaldehyde, 5\% glacial acetic acid). The samples were sent to the Xinjiang Institute of Ecology and Geography Chinese Academy of Science where photographs were made using an electron scanning

\section{Results}

Leaf water potential decreased significantly as drought stress increased (Fig. 1). Leaf water potentials were $30 \%$ lower under MS and 58\% lower under MDS compared with WW.

Leaf dimensions: Drought stress significantly reduced leaf area and leaf thickness but increased LMA and leaf density (Table 1S, supplement available online). Leaf surface area was 37\% lesser under MS and 53\% lesser under MDS compared with WW. Leaf thickness was reduced by $9.7 \%$ in the MS treatment and by $24.2 \%$ in the MDS treatment. The LMA was $8.6 \%$ greater in the MS treatment and $33.3 \%$ greater in the MDS treatment compared with WW. Similarly, the MS and MDS treatments increased leaf density by 19.7 and $74.9 \%$, respectively. microscope (SUPRA 55VP, Carl Zeiss AG, Oberkochen, Germany). The lengths and widths of the stomata and stomatal pores were measured with ImageJ software. Stomatal density was calculated as the number of stomata per unit leaf area. Stomatal pore area and stomatal pore perimeter were calculated based on the methods of Zhou and Xie (2016).

Theoretical $g_{\mathrm{s}}$ and theoretical maximum $g_{\mathrm{s}}$ were calculated for both the abaxial and adaxial sides based on the following equation (Franks and Farquhar 2001):

$$
g_{\mathrm{s}}=\frac{(\text { diffusion coefficient }) \times(\text { stomata density }) \times(\text { pore area })}{(\text { molar volume of air }) \times[\text { (pore depth })+\frac{\pi}{2} \sqrt{\text { pore } \frac{\text { area }}{\pi}}}
$$

when calculating theoretical $g_{\mathrm{s}}$, pore depth was estimated based on pore width using the following equation (Franks and Beerling 2009):

$$
\text { Pore depth }=[(\text { stomata width }- \text { pore width }) / 2]
$$

For maximum theoretical $g_{\mathrm{s}}$, pore depth was estimated based on stomatal width using the following equation (Franks and Farquhar 2007):

Pore depth $=($ stomata width/2) .

In both calculations, the molar volume of air and the effective diffusion coefficient for water vapor in air were those for $21^{\circ} \mathrm{C}$.

Statistical analysis: One-way analysis of variance was conducted using SPSS 19.0 for Windows (SPSS, Chicago, USA). The significance of the differences between treatment means was separated using the Student-NewmanKeul's test at the $P \leq 0.05$ level. The data are presented as the means $\pm \mathrm{SD}$. Linear regressions were performed using SigmaPlot version 10.

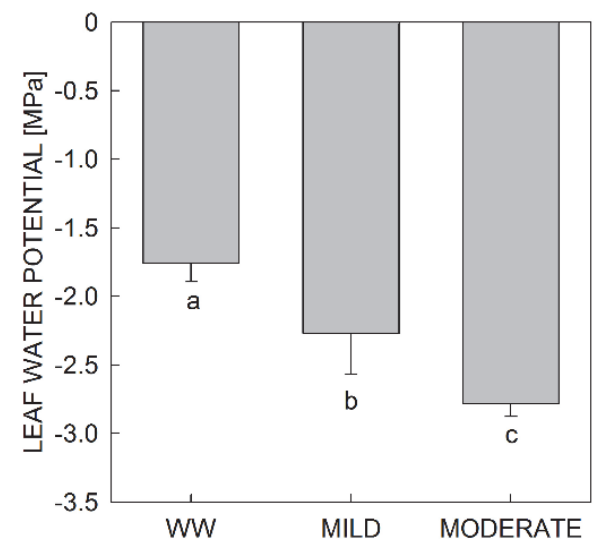

Fig. 1. Effect of drought stress on cotton leaf water potential. Error bars represent SD. Values with different letters are significantly different at $P<0.05$. WW - well-watered treatment. 
Vein density: Drought stress significantly increased vein density per unit leaf area (Table 1; Fig. 1S, supplement available online). Major vein density was $26.2 \%$ greater under MS and $40.5 \%$ greater under MDS compared with WW. Similarly, the MS and MDS treatments increased minor vein density per unit leaf area by 9.6 and $36.8 \%$, respectively. Minor vein density per unit leaf volume was also significantly greater in the MS and MDS treatments than that in WW. Drought stress influenced the distance from the stomata to the veins. On the adaxial leaf side, the average distance from the stomata to the vein decreased significantly in the order $\mathrm{WW}>\mathrm{MS}>\mathrm{MDS}$. On the abaxial leaf side, the order was MS $>$ WW, MDS.

Stomata characteristics: Drought stress significantly reduced stomata length on the abaxial leaf side but not on the adaxial leaf side (Table 2). Stomata width was not significantly affected by drought stress; however, stomata width was significantly greater $(18.3-41.7 \%)$ on the abaxial rather than that on adaxial leaf side. MDS significantly reduced stomata pore perimeter on the adaxial leaf side by $14 \%$ compared with WW, whereas MS had no significant effect. On the abaxial leaf side, the MS and MDS treatments reduced stomata pore perimeter by 28.2 and $33.4 \%$, respectively, compared with WW.

The stomata pore area per unit leaf area was $132-235 \%$ greater on the abaxial side than that on the adaxial side (Table 2). Drought stress had no significant effect on stomata pore area on the adaxial leaf side. However, on the abaxial side, the MS and MDS treatments reduced stomata pore area by $13.5 \%$ and $15.4 \%$, respectively, compared with WW.

Stomata density was 22,100 , and $144 \%$ greater on the adaxial side than that on the adaxial side in WW, MS, and MDS treatments, respectively (Table 2). The MDS treatment increased stomata density on the adaxial side by $22 \%$ compared with WW, whereas MS treatment had no significant effect. On the abaxial side, the MS and MDS treatments increased stomata density by 40 and $134 \%$, respectively, compared with WW.

Total stomata density and pore area: The ratio of adaxial:abaxial stomata density decreased significantly as drought stress increased (Table $2 \mathrm{~S}$, supplement available online). In contrast, ratio of sum of the total adaxial and abaxial stomata density per unit vein density increased significantly as drought stress increased. The MS and MDS treatments both reduced total adaxial and abaxial stomatal pore area per unit leaf area. MDS significantly reduced the total adaxial and abaxial stomatal pore area per unit leaf volume, whereas MS had no significant effect.

Gas exchange: Leaf $P_{\mathrm{N}}, g_{\mathrm{s}}, E$, and $C_{\mathrm{i}}$ decreased significantly in the order WW $>$ MS $>$ MDS (Table 3 ). The WUE (i.e., $P_{\mathrm{N}} / E$ ) in the MDS treatment was $9.4 \%$ greater than that in the MS treatment and $3.1 \%$ greater than that in the WW treatment. There was no significant difference in WUE between the MS treatment and WW. The intrinsic $\mathrm{WUE}_{\mathrm{i}}\left(\right.$ i.e., $\left.P_{\mathrm{N}} / \mathrm{g}_{\mathrm{s}}\right)$ increased significantly as drought stress increased.

Table 1. Effect of drought stress on the leaf vein characteristics of cotton. Values are means \pm SD. Values within a column followed by different letters are significantly different at $P<0.05$. Major veins are those which extend from the petiole. Minor veins are all but the major veins. MS - mild stress; MDS - moderate stress; WW - well-watered.

\begin{tabular}{|c|c|c|c|c|c|}
\hline \multirow[t]{2}{*}{ Treatment } & \multirow[t]{2}{*}{$\begin{array}{l}\text { Major vein density } \\
{\left[\mathrm{cm} \mathrm{cm}^{-2}\right]}\end{array}$} & \multirow[t]{2}{*}{$\begin{array}{l}\text { Minor vein density } \\
{\left[\mathrm{cm} \mathrm{cm}^{-2}\right]}\end{array}$} & \multirow[t]{2}{*}{$\begin{array}{l}\text { Minor vein density } \\
{\left[\mathrm{cm} \mathrm{cm}^{-3}\right]}\end{array}$} & \multicolumn{2}{|c|}{$\begin{array}{l}\text { Distance from stomata to vein } \\
{[\mu \mathrm{m}]}\end{array}$} \\
\hline & & & & Adaxial & Abaxial \\
\hline WW & $0.42 \pm 0.03^{\mathrm{c}}$ & $12.52 \pm 0.40^{\mathrm{c}}$ & $31.25 \pm 0.25^{\mathrm{c}}$ & $283.7 \pm 15.1^{\mathrm{a}}$ & $143.8 \pm 5.6^{\mathrm{b}}$ \\
\hline MS & $0.53 \pm 0.02^{b}$ & $13.68 \pm 0.36^{b}$ & $37.75 \pm 0.01$ & $226.6 \pm 13.8^{b}$ & $162.0 \pm 6.9^{\mathrm{a} a}$ \\
\hline MDS & $0.59 \pm 0.02^{\mathrm{a}}$ & $17.07 \pm 0.30^{\mathrm{a}}$ & $56.24 \pm 1.35^{\mathrm{a}}$ & $191.4 \pm 7.4^{\mathrm{c}}$ & $137.9 \pm 1.7^{\mathrm{b}}$ \\
\hline
\end{tabular}

Table 2. Effects of drought stress on the stomata characteristics of cotton leaves. Values are means \pm SD. Values within a column followed by different letters are significantly different at $P<0.05$. MS - mild stress; MDS - moderate stress; WW - well-watered.

\begin{tabular}{lllllll}
\hline Leaf side & Treatment & $\begin{array}{l}\text { Stomata length Stomata width } \\
{[\mu \mathrm{m}]}\end{array}$ & $\begin{array}{l}\text { Stomatal pore } \\
\text { perimeter } \\
{[\mu \mathrm{m}]}\end{array}$ & $\begin{array}{l}\text { Stomatal pore area } \\
{\left[\times 10^{-3} \mu \mathrm{m}^{2} \mu \mathrm{m}^{-2}\right]}\end{array}$ & $\begin{array}{l}\text { Stomata density } \\
{\left[\text { stomata } \mathrm{mm}^{-2}\right]}\end{array}$ \\
\hline Adaxial & WW & $27.3 \pm 0.2^{\mathrm{bc}}$ & $15.3 \pm 0.9^{\mathrm{b}}$ & $30.7 \pm 2.8^{\mathrm{b}}$ & $3.8 \pm 0.61^{\mathrm{c}}$ & $167.7 \pm 20.2^{\mathrm{d}}$ \\
& MS & $27.6 \pm 0.5^{\mathrm{b}}$ & $16.9 \pm 0.4^{\mathrm{b}}$ & $30.1 \pm 1.5^{\mathrm{b}}$ & $3.3 \pm 0.72^{\mathrm{c}}$ & $150.0 \pm 20.2^{\mathrm{d}}$ \\
& MDS & $27.0 \pm 0.8^{\mathrm{bcd}}$ & $16.9 \pm 0.5^{\mathrm{b}}$ & $26.4 \pm 1.5^{\mathrm{c}}$ & $3.1 \pm 0.29^{\mathrm{c}}$ & $205.2 \pm 1.5^{\mathrm{c}}$ \\
Abaxial & WW & $30.0 \pm 0.6^{\mathrm{a}}$ & $21.6 \pm 0.7^{\mathrm{a}}$ & $34.4 \pm 1.7^{\mathrm{a}}$ & $10.4 \pm 0.63^{\mathrm{a}}$ & $214.0 \pm 3.8^{\mathrm{c}}$ \\
& MS & $26.4 \pm 0.6^{\mathrm{cd}}$ & $20.2 \pm 0.5^{\mathrm{a}}$ & $24.7 \pm 1.0^{\mathrm{cd}}$ & $9.0 \pm 0.25^{\mathrm{b}}$ & $300.0 \pm 13.8^{\mathrm{b}}$ \\
& MDS & $26.3 \pm 0.38^{\mathrm{d}}$ & $20.0 \pm 30.4^{\mathrm{a}}$ & $22.9 \pm 0.4^{\mathrm{d}}$ & $8.8 \pm 0.80^{\mathrm{b}}$ & $500.8 \pm 10.1^{\mathrm{a}}$ \\
\hline
\end{tabular}


Theoretical stomatal conductance: Theoretical $g_{\text {s }}$ was significantly greater on the abaxial side than that on the adaxial side (Fig. $2 A$ ). On the adaxial side, theoretical $g_{\mathrm{s}}$ was not significantly affected by drought stress. However, on the abaxial side, theoretical $g_{\mathrm{s}}$ decreased in the order WW $>$ MDS $>$ MS. The same trend was observed for maximum theoretical $g_{\mathrm{s}}$, except that on the abaxial side, maximum theoretical $g_{\mathrm{s}}$ was significantly greater under moderate stress than under either mild stress or WW (Fig. 2B).
Relationship between stomata density and vein density: Vein density was positively and significantly correlated with stomata density on both the adaxial and abaxial sides (Fig. 3A,B). Similarly, total stomata density was significantly positively correlated with vein density per unit leaf area and with vein density per unit leaf volume (Fig. 3C,D)

Table 3. Effects of drought stress on the stomatal conductance $\left(g_{\mathrm{s}}\right)$, leaf photosynthetic rate (leaf $\left.P_{\mathrm{N}}\right)$, transpiration rate $(E)$, intercellular $\mathrm{CO}_{2}$ concentration $\left(C_{\mathrm{i}}\right)$, water-use efficiency $\left(\mathrm{WUE}=P_{\mathrm{N}} / \mathrm{E}\right)$, and intrinsic water-use efficiency $\left(\mathrm{WUE}_{\mathrm{i}}=P_{\mathrm{N}} / g_{\mathrm{s}}\right)$ of cotton leaves. Values are means $\pm \mathrm{SD}$. Values within a column followed by different letters are significantly different at $P<0.05$. MS - mild stress; MDS moderate stress; WW - well-watered.

\begin{tabular}{|c|c|c|c|c|c|c|}
\hline Treatment & $\begin{array}{l}g_{\mathrm{s}} \\
{\left[\mathrm{mol}\left(\mathrm{H}_{2} \mathrm{O}\right) \mathrm{m}^{-2} \mathrm{~s}^{-1}\right]}\end{array}$ & $\begin{array}{l}P_{\mathrm{N}} \\
{\left[\operatorname{mol}\left(\mathrm{CO}_{2}\right) \mathrm{m}^{-2} \mathrm{~s}^{-1}\right]}\end{array}$ & $\begin{array}{l}E \\
{\left[\mathrm{mmol}\left(\mathrm{H}_{2} \mathrm{O}\right) \mathrm{m}^{-2} \mathrm{~s}^{-1}\right]}\end{array}$ & $\begin{array}{l}C_{\mathrm{i}} \\
{\left[\mu \mathrm{mol}\left(\mathrm{CO}_{2}\right) \mathrm{mol}^{-1}\right]}\end{array}$ & $\begin{array}{l}\text { WUE } \\
{\left[\mu \mathrm{mol}\left(\mathrm{CO}_{2}\right) \operatorname{mol}\left(\mathrm{H}_{2} \mathrm{O}\right)\right]}\end{array}$ & $\begin{array}{l}\mathrm{WUE}_{\mathrm{i}} \\
{\left[\mu \mathrm{mol}\left(\mathrm{CO}_{2}\right) \operatorname{mmol}\left(\mathrm{H}_{2} \mathrm{O}\right)\right]}\end{array}$ \\
\hline WW & $1.2 \pm 0.1^{\mathrm{a}}$ & $35 \pm 0.9^{\mathrm{a}}$ & $11.0 \pm 0.3^{\mathrm{a}}$ & $251 \pm 5.3^{\mathrm{a}}$ & $3.2 \pm 0.1^{\mathrm{b}}$ & $30.2 \pm 3.2^{\mathrm{c}}$ \\
\hline MS & $0.5 \pm 0.1^{\mathrm{b}}$ & $28 \pm 2.8^{\mathrm{b}}$ & $8.4 \pm 0.7^{b}$ & $219 \pm 4.5^{b}$ & $3.3 \pm 0.1^{\mathrm{b}}$ & $61.3 \pm 6.0^{\mathrm{b}}$ \\
\hline MDS & $0.2 \pm 0.1^{\mathrm{c}}$ & $18 \pm 4.8^{c}$ & $5.2 \pm 1.2^{\mathrm{c}}$ & $174 \pm 20.1^{\mathrm{c}}$ & $3.5 \pm 0.2^{\mathrm{a}}$ & $106.7 \pm 17.2^{\mathrm{a}}$ \\
\hline
\end{tabular}

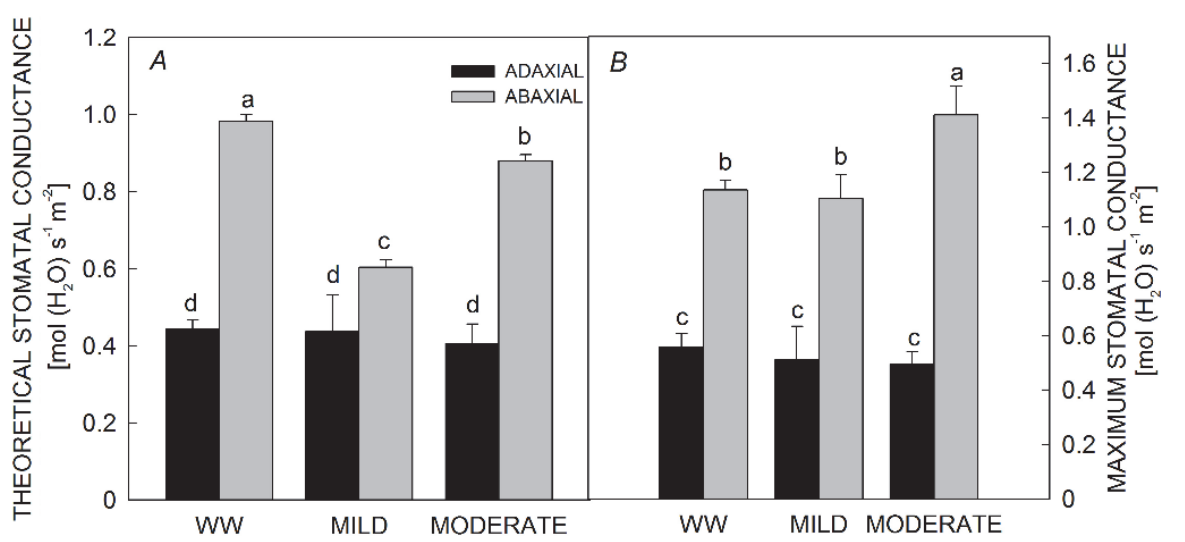

Relationships between vein and stomatal density and WUE: Vein density was significantly positively correlated on both a leaf area and a leaf volume basis with WUE (Fig. 4A,B). Stomatal density was also positively correlated $\mathrm{WUE}_{\mathrm{i}}$ (Fig. 4C,D). Stomatal pore area (on both a leaf

\section{Discussion}

Coordinated relationship between stomata density and vein density: As the exit point for water and the entrance point for $\mathrm{CO}_{2}$, stomata are at the core of leaf structural diversity. The vein network is important because it distributes water and nutrients throughout the plant. A cost-optimal use of water resources requires the homogenous distribution of veins and stomata; that is, the density of these two structures should remain coordinated (Fiorin et al. 2015).

Many studies have shown coordinated development between vein density and stomata density. For example, Brodribb and Jordan (2011) observed that the development of veins and stomata was coordinated in evergreen trees (Nothofagus cunninghamii). Correlated evolution between on the adaxial leaf showed no significant correlation with $g_{\mathrm{s}}, P_{\mathrm{N}}, E$, and $\mathrm{WUE}_{\mathrm{i}}$ (Fig. 5). On the abaxial side, stomatal pore area per unit leaf area was significantly negatively correlated with $\mathrm{WUE}_{\mathrm{i}}$ and significantly positively correlated with $g_{\mathrm{s}}, P_{\mathrm{N}}$, and $E$. stomatal traits and vein density also exists in Paphiopedilum (Zhang et al. 2012). In the leaves of a woody angiosperm (Toona ciliata M. Roem.), the differential between vein density and stomata density was regulated by leaf expansion so that leaf hydraulic conductance and $g_{\mathrm{s}}$ remained proportional (Carins et al. 2012). In this study, cotton was grown under increasing drought stress. The results showed that vein density per unit leaf area was positively correlated with stomata density per unit leaf area on both the abaxial and adaxial leaf sides (Fig. 3). Furthermore, total adaxial and abaxial stomata density per unit leaf area was significantly positively correlated with vein density per unit leaf area. These results indicate a coordinated relationship between 
vein density and stomata density. We propose that this coordinated relationship is essential for maintaining the dynamic balance of water loss and supply in plant leaves. Leaf water transport is affected by several leaf morphological traits including leaf thickness, the depth of the veins inside the leaves, and leaf vein density (Noblin et al. 2008, Buckley et al. 2015). Previous studies only considered the relationship between stomata and veins on a leaf area basis. In this study, drought reduced leaf thickness (Table 1S). Our analysis also indicated that a coordinated relationship existed between stomata density and vein density on a leaf volume basis (Fig. 3). Drought stress significantly reduced the distance from the stomata to the vein on the adaxial leaf side (Table 1). In contrast, the distance from the stomata to the vein was relatively stable on the abaxial side, regardless of the drought stress treatment. These results suggest that the stability of the distance from the stomata to vein on the abaxial side is important for cotton under drought stress.

During photosynthesis, $\mathrm{CO}_{2}$ moves through stomata into mesophyll cells. When the stomata are open, the supply of $\mathrm{CO}_{2}$ increases, thus benefiting photosynthesis. However, water transport capacity is required to keep the stomata open. High stomata density and high vein density must appear simultaneously. If not, stomata must be partially closed (Dow and Bergmann 2014). Furthermore, we found that drought stress significantly increased the ratio of stomatal density to vein density (Table $2 \mathrm{~S}$ ). This may mean that veins improve the ability of the plant to indirectly support stomatal opening. We speculate that photosynthesis would benefit from open stomata as a result of increasing vein density when plants are recovering from drought stress (Lauriano et al. 2004, Chaves and Oliveira 2004).

Vein and stomata density in ferns and angiosperms is determined by epidermal cell size (Zhao et al. 2017). In this study, drought stress reduced the size of both mesophyll and epidermal cells, resulting in smaller leaves. As mesophyll cells become smaller, the veins are nearer each other; thus vein density increases (Table 1). Higher
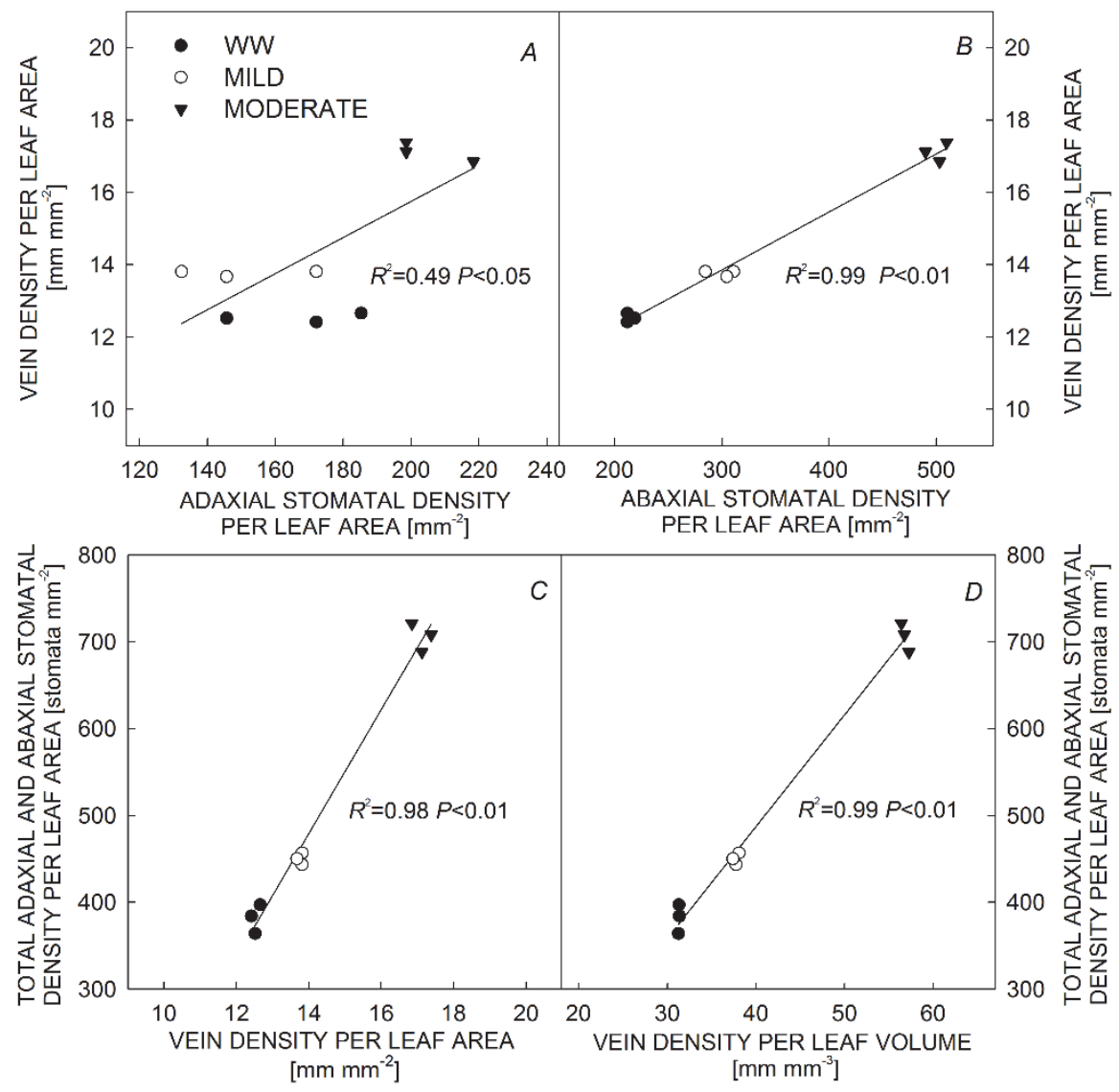

Fig. 3. Correlation between vein density and stomata density on the adaxial $(A)$ and abaxial $(B)$ leaf sides of cotton as affected by drought stress. Correlation between stomata density and vein density per unit leaf area $(C)$ and per unit leaf volume $(D)$. WW well-watered. 


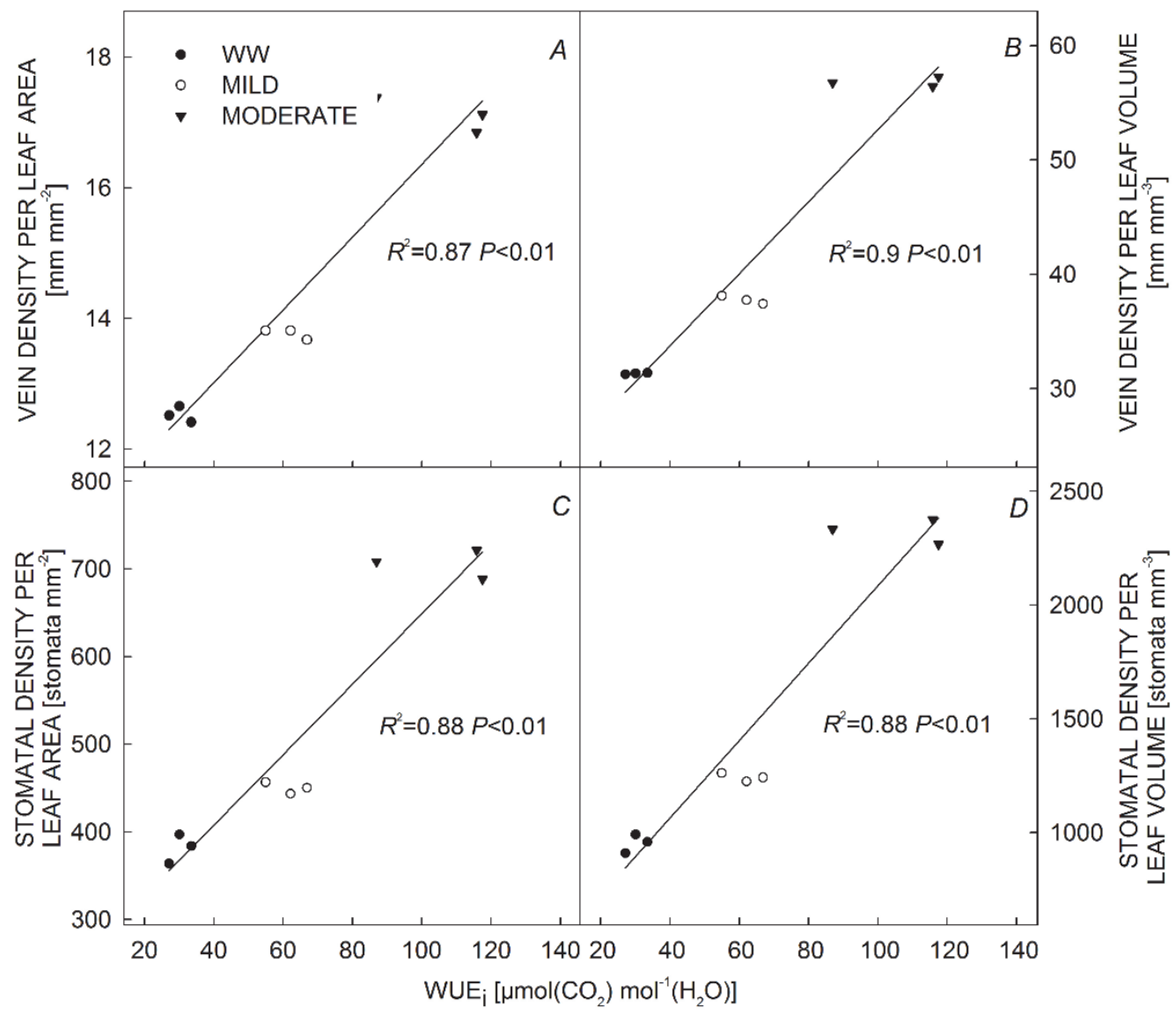

Fig. 4. Correlation between intrinsic water-use efficiency (WUE $))$ and vein density per unit area $(A)$ and per unit leaf volume $(B)$ in cotton as affected by drought stress. Correlation between $W U E_{i}$ and stomata density per unit leaf area $(C)$ and per unit leaf volume $(D)$. WW - well-watered.

stomata density in the drought stress treatments may be because the smaller epidermal cells are closely packed and epidermal cell expansion is reduced (Hsie et al. 2015). Under drought conditions, a reduction in leaf size allows plants to reduce transpiration and increase WUE (Table 3).

Coordination between stomata density and vein density may improve WUE under drought: As expected, the WUE and $W^{-} E_{i}$ of cotton increased under drought stress (Table 3). Water transport efficiency is closely linked with leaf veins. A high density of first order veins equalizes the water potential across the leaf (Zwieniecki et al. 2004, Ocheltree et al. 2008). In this study, major vein density increased under water stress (Table 1). Acting as water transport superhighways, the major veins can efficiently distribute limited water resources across the leaf, thus increasing WUE. In addition, a high density of first-order (i.e., major) veins improves drought resistance (Sack and Scoffoni 2013).

Generally speaking, high vein density represents a larger number of parallel exit pathways of water. Brodribb et al. (2007) examined 43 plant species and observed that permeable xylem surface area increased as vein density increased. The increase of vein density per unit leaf area or leaf volume means that the indirect or direct area between vein and mesophyll cells changes incrementally, so that under drought stress, the veins can efficiently transport urgently needed water to mesophyll cells for photosynthesis. A previous report indicated that high vein density in Populus deltoides leaves may contribute to greater phloem transport (Russin and Evert 1984) and higher rates of gas exchange per unit leaf area (Sack and Frole 2006, Brodribb et al. 2007, Boyce et al. 2009, Brodribb and Jordan 2010, McKown et al. 2010, Feild et al. 2011, Walls 2011). Higher vein density can also increase the efficient transport of materials to where they are needed in the plant, so that plant growth increases after rewatering (Lauriano et al. 2004, Chaves and Oliveira 2004).

In this study, stomata density was well correlated with WUE $_{\mathrm{i}}$ (Fig. 4). Stomata density and stomata size showed negative correlation in Eucalyptus globulus (Franks et al. 2009a,b). Previous researchers proposed that small stomata can rapidly respond to changes in the external environment (Xu and Zhou 2008, Zhang et al. 2012, Drake et al. 2013). In this study, drought stress reduced stomata size on the abaxial leaf side (Table 2). The decrease in 


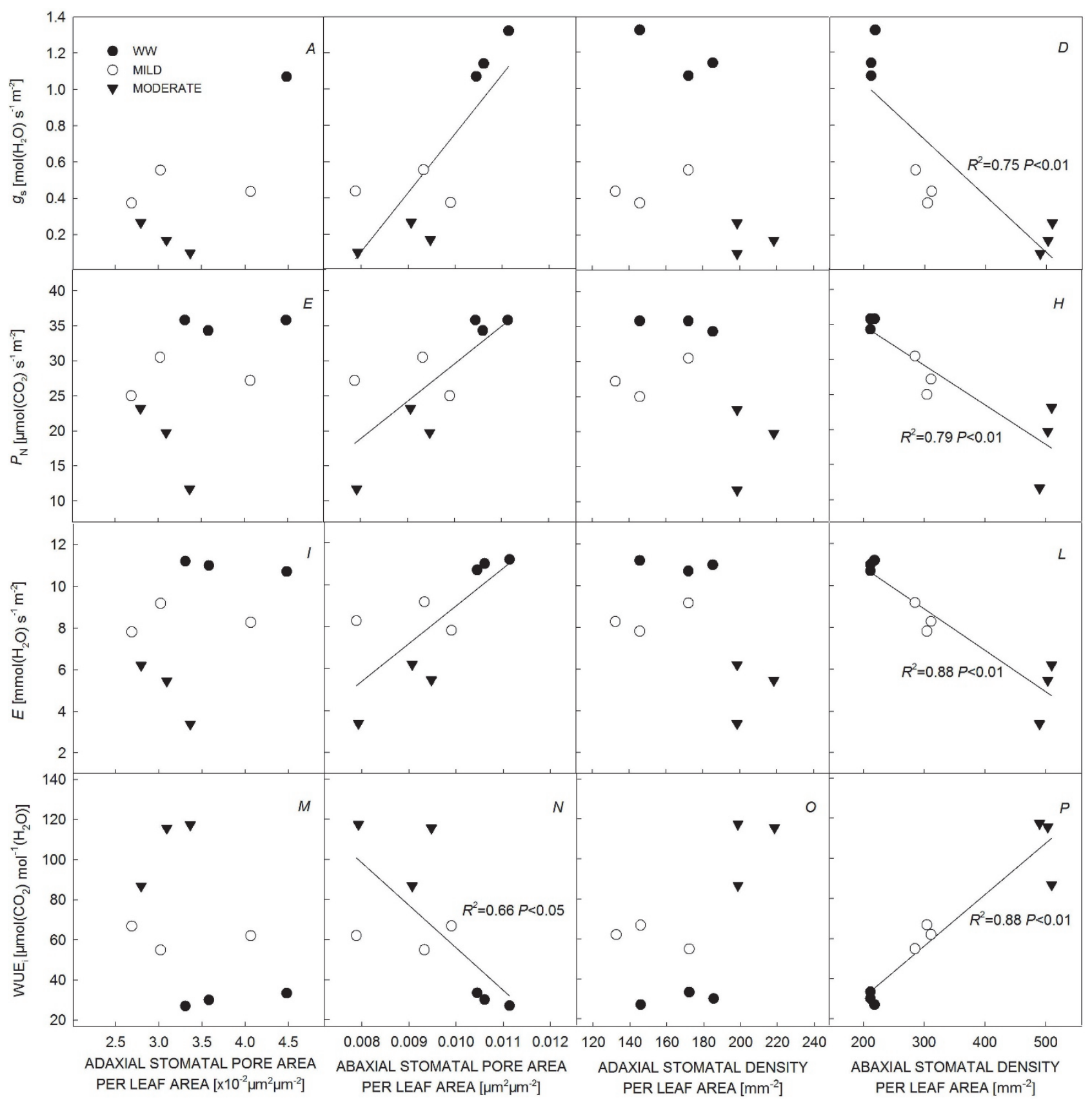

Fig. 5. Correlation between stomatal conductance $\left(g_{\mathrm{s}}\right)$ and stomata pore area $(A-B)$ and stomata density $(C-D)$ in cotton as affected by drought stress $(E-H)$. Correlation between leaf net photosynthesis $\left(P_{\mathrm{N}}\right)$ and stomatal pore area $(E-F)$ and stomata density $(G-H)$. $(I-L)$ correlation between transpiration $(E)$ and stomatal pore area $(I-J)$ and stomata density $(K-L)$. $(M-P)$ correlation between intrinsic water-use efficiency (WUEi) and stomatal pore area $(M-N)$ and stomatal pore density $(O-P)$. WW - well-watered treatment.

stomata size allows cotton to quickly and sensitively regulate leaf gas exchange and increase WUE. This suggested that drought-induced increases in stomata density may improve $\mathrm{WUE}_{\mathrm{i}}$. Taken together, the coordinated relationship between stomata density and vein density may contribute to the improvement of WUE.

The abaxial leaf side is more important than the adaxial side in gas exchange and water-use efficiency under drought: Previous studies indicated that under normal conditions, adaxial $g_{\mathrm{s}}$ is lesser than abaxial $g_{\mathrm{s}}(\mathrm{Lu}$ et al. 1993, Wang et al. 2008). Operating $g_{\mathrm{s}}$ was also lesser on the adaxial side than that on the abaxial side (Fanourakis et al. 2015). This suggests that the abaxial side plays a more important role than the adaxial side in gas exchange under normal conditions. In our study, the adaxial:abaxial stomata density decreased as drought stress increased (Table 2S). In addition, theoretical $g_{\mathrm{s}}$ and 
maximum theoretical $g_{\mathrm{s}}$ were lesser on the adaxial side than that on the abaxial size (Fig. 2). These results show that under water stress, the abaxial side contributes more to gas exchange than the adaxial side. We also found that gas exchange was significantly correlated with stomatal density and stomatal pore area on the abaxial side but not on the adaxial side (Fig. 5).

From our perspective, preventing water loss and improving WUE are prerequisites for the survival of plants under drought conditions. Theoretic $g_{s}$ and theoretic maximum $g_{\mathrm{s}}$ are both low on the adaxial side (Fig. 2). This not only prevents water loss but also limits the $\mathrm{CO}_{2}$ supply to chloroplasts. This suggests that the adaxial side of cotton leaves may contribute less than the abaxial side to photosynthesis. Although it is the dominant side for transpiration under normal conditions, low $g_{\mathrm{s}}$ limits water loss from the adaxial leaf side during drought stress.

Rockwell et al. (2014) studied mature red oak (Quercus rubra L.) trees and found that increases in the air fraction can increase the competitiveness of vapor transport at the transition to the spongy mesophyll. Recent modeling approaches have discovered that water inside the leaves is transported mainly through the liquid; however,

\section{References}

Boyce C.K., Brodribb T.J., Feild T.S. et al.: Angiosperm leaf vein evolution was physiologically and environmentally transformative. - P. Roy. Soc. B-Biol. Sci. 276: 177-776, 2009.

Brodribb T.J., Feild T.S.: Stem hydraulic supply is linked to leaf photosynthetic capacity: evidence from New Caledonian and Tasmanian rainforests. - Plant Cell Environ. 23: 1381-1388, 2000.

Brodribb T.J., Feild T.S., Jordan G.J.: Leaf maximum photosynthetic rate and venation are linked by hydraulics. - Plant Physiol. 144: 1890-1898, 2007.

Brodribb T.J., Jordan G.J.: Water supply and demand remain balanced during leaf acclimation of Nothofagus cunninghamii trees. - New Phytol. 192: 437-448, 2011.

Buckley T.N., John G.P., Scoffoni C. et al.: How does leaf anatomy influence water transport outside the xylem? - Plant Physiol. 168: 1616-1635, 2015.

Carins M.R., Jordan G.J., Brodribb T.J.: Differential leaf expansion can enable hydraulic acclimation to sun and shade. - Plant Cell Environ. 35: 1407-1418, 2012.

Chaves M.M., Oliveira M.M.: Mechanisms underlying plant resilience to water deficits: prospects for water-saving agriculture. - J. Exp. Bot. 55: 2365-2384, 2004.

Costa J.M., Ortuño M.F., Chaves M.M. et al.: Deficit irrigation as a strategy to save water: physiology and potential application to horticulture. - J. Integr. Plant Biol. 49: 1421-1434, 2007.

Dow G.J., Bergmann D.C.: Patterning and processes: how stomatal development defines physiological potential. - Curr. Opin. Plant Biol. 21: 67-74, 2014.

Drake P.L., Froend R.H., Franks P.J.: Smaller, faster stomata: scaling of stomatal size, rate of response, and stomatal conductance. - J. Exp. Bot. 64: 495-505, 2013.

Fanourakis D., Giday H., Milla R. et al.: Pore size regulates operating stomatal conductance, while stomatal densities drive the partitioning of conductance between leaf sides. - Ann. Bot.- in leaves with low tissue density, the vapor phase may also have a significant role in water transport under high irradiance and high temperatures (Rockwell et al. 2014, Buckley 2015). A 10\% increase in leaf mass per unit area reduced the airspace fraction by about $2 \%$ in 11 simpleleaved woody angiosperm species (John et al. 2017). The airspace fraction of spongy tissue is high and nearly twice that of palisade tissue. As a result, cell-to-cell connectivity in spongy tissue is low, which effectively decreases the area available for liquid-phase flow. Therefore, spongy mesophyll is more resistive compared with other tissues (Buckley et al. 2015). Leaf thickness decreases and leaf density increases as water stress increases (Table 1S). The explanation is that water stress may increase the number of mesophyll cells (especially in spongy tissue), thus reducing leaf airspace. The reduction in airspace may limit transpiration from the abaxial side. Our results show that theoretic conductance is greater on the abaxial side than on the adaxial side (Fig. 2); therefore, $\mathrm{CO}_{2}$ entering the abaxial side may prevent water loss. Overall, under drought conditions, the abaxial side may play a more important role in gas exchange and water use efficiency compared with the adaxial side.

London 115: 555-565, 2015.

Feild T.S., Brodribb T.J., Iglesias A. et al.: Fossil evidence for Cretaceous escalation in angiosperm leaf vein evolution. - P. Natl. Acad. Sci. USA 108: 8363-8366, 2011.

Fiorin L., Brodribb T.J., Anfodillo T.: Transport efficiency through uniformity: organization of veins and stomata in angiosperm leaves. - New Phytol. 209: 216-227, 2015.

Flexas J., Galmés J., Gallé A. et al.: Improving water use efficiency in grapevines: potential physiological targets for biotechnological improvement. - Aust. J. Grape Wine R. 16: 106-121, 2010.

Flexas J., Niinemets Ü., Gallé A. et al.: Diffusional conductances to $\mathrm{CO}_{2}$ as a target for increasing photosynthesis and photosynthetic water-use efficiency. - Photosynth. Res. 117: 45-59, 2013.

Franks P.J., Beerling D.J.: Maximum leaf conductance driven by $\mathrm{CO}_{2}$ effects on stomatal size and density over geologic time. P. Natl. Acad. Sci. USA 106: 10343-10347, 2009.

Franks P.J., Beerling D.J., Berner R.A.: Maximum leaf conductance driven by $\mathrm{CO}_{2}$ effects on stomatal size and density over geologic time. - P. Natl. Acad. Sci. USA 106: 10343-10347, 2009a.

Franks P.J., Doheny-Adams W., Britton-Harper T. et al: Increasing water use efficiency directly through genetic manipulation of stomatal density. - New Phytol. 207: 188-195, 2015.

Franks P.J., Drake P.L., Beerling D.J.: Plasticity in maximum stomatal conductance constrained, by negative correlation between stomatal size and density: an analysis using Eucalyptus globulus. - Plant Cell Environ. 32: 1737-1748, 2009b.

Franks P.J., Farquhar G.D. The mechanical diversity of stomata and its significance in gas-exchange control. - Plant Physiol. 143: 78-87, 2007. 
Franks P.J., Farquhar G.D. The effect of exogenous abscisic acid on stomatal development, stomatal mechanics, and leaf gas exchange in Tradescantia virginiana. - Plant Physiol. 125: 935-942, 2001.

Gago J., Douthe C., Florez-Sarasa I. et al.: Opportunities for improving leaf water use efficiency under climate change conditions. - Plant Sci. 226: 108-119, 2014.

Gitz D.C., Liu-Gitz L., Britz S.J. et al.: Ultraviolet-B effects on stomatal density, water-use efficiency, and stable carbon isotope discrimination in four glasshouse-grown soybean (Glyicine max) cultivars. - Environ. Exp. Bot. 53: 343-355, 2005.

Hsie B.S., Mendes K.R., Antunes W.C. et al.: Jatropha curcas L. (Euphorbiaceae) modulates stomatal traits in response to leafto-air vapor pressure deficit. - Biomass Bioenerg. 81: 273-281, 2015.

Hu J., Yang Q.Y., Huang W. et al.: Effects of temperature on leaf hydraulic architecture of tobacco plants. - Planta 240: 489-496, 2014.

John G.P., Scoffoni C., Buckley T.N. et al.: The anatomical and compositional basis of leaf mass per area. - Ecol. Lett. 20: 412425, 2017.

Küppers M.: Carbon relations and competition between woody species in a Central European hedgerow. - Oecologia 64: 344354,1984

Lauriano J.A., Ramalho J.C., Lidon F.C. et al.: Peanut photosynthesis under drought and re-watering. - Photosynthetica 42: 37-41, 2004.

Lu Z., Quiñones M.A., Zeiger E.: Abaxial and adaxial stomata from Pima cotton (Gossypium barbadense L.) differ in their pigment content and sensitivity to light quality. - Plant Cell Environ. 16: 851-858, 1993.

McKown A.D., Cochard H., Sack L.: Decoding leaf hydraulics with a spatially explicit model: principles of venation architecture and implications for its evolution. - Am. Nat. 175: 447460, 2010

Meinzer F.C., Grantz D.A.: Coordination of stomatal, hydraulic, and canopy boundary layer properties: Do stomata balance conductances by measuring transpiration? - Physiol. Plantarum 83: 324-329, 1991.

Morison J.I., Baker N.R., Mullineaux P.M. et al.: Improving water use in crop production. - Philos. T. Roy. Soc. B 363: 639658,2008

Noblin X., Mahadevan L., Coomaraswamy I.A. et al.: Optimal vein density in artificial and real leaves. - P. Natl. Acad. Sci. USA 105: 9140-9144, 2008.

Ocheltree T.W., Nippert J.B., Prasad P.V.: Changes in stomatal conductance along grass blades reflect changes in leaf structure. - Plant Cell Environ. 35: 1040-1049, 2008.
Parry M.A.J., Flexas J., Medrano H.: Prospects for crop production under drought: research priorities and future directions. - Ann. Appl. Biol. 147: 211-226, 2005.

Philip J.R.: Plant water relations: some physical aspects. - Annu. Rev. Plant Physio. 17: 245-268, 2003.

Rockwell F.E., Holbrook N.M., Stroock A.D.: The competition between liquid and vapor transport in transpiring leaves. Plant Physiol. 164: 1741, 2014.

Russin W.A., Evert R.F.: Studies on the leaf of Populus deltoides (Salicaceae): Morphology and anatomy. - Am. J. Bot. 71: 1398-1415, 1984.

Sack L., Frole K.: Leaf structural diversity is related to hydraulic capacity in tropical rain forest trees. - Ecology 87: 483-491, 2006.

Sack L., Holbrook N.M.: Leaf hydraulics. - Annu. Rev. Plant Biol. 57: 361-381, 2006.

Sack L., Scoffoni C.: Leaf venation: structure, function, development, evolution, ecology and applications in the past, present and future. - New Phytol. 198: 983-1000, 2013.

Sharpe P.J.H.: Adaxial and abaxial stomatal resistance of cotton in the field. - Agron. J. 65: 570-574, 1973.

Walls R.L.: Angiosperm leaf vein patterns are linked to leaf functions in global-scale data set. - Am. J. Bot. 98: 244-53, 2011.

Wang Y., Noguchi K., Terashima I.: Distinct light responses of the adaxial and abaxial stomata in intact leaves of Helianthus annuus L. - Plant Cell Environ. 31: 1307-1316, 2008.

Xu Z., Zhou G.: Responses of leaf stomatal density to water status and its relationship with photosynthesis in a grass. $-\mathrm{J}$. Exp. Bot. 59: 3317-3325, 2008.

Yoo C.Y., Pence H.E., Jin J.B. et al.: The Arabidopsis GTL1 transcription factor regulates water use efficiency and drought tolerance by modulating stomatal density via transrepression of SDD1. - Plant Cell 22: 4128-4141, 2010.

Zhang S.B., Guan Z.J., Sun M. et al.: Evolutionary association of stomatal traits with leaf vein density in Paphiopedilum, Orchidaceae. - PLoS ONE 7: e40080, 2012.

Zhao W.L., Siddiq Z., Fu P.L. et al.: Stable stomatal number per minor vein length indicates the coordination between leaf water supply and demand in three leguminous species. - Sci. Rep. 7: 2211, 2017.

Zhou C.B., Xie C.: A simple method to quantify the size and shape of stomatal pore. - In: The Proceedings of the $17^{\text {th }}$ International Congress on Photosynthesis Research, Aug. 7-12 2016. Maastricht 2016.

Zwieniecki M.A., Boyce C.K., Holbrook N.M.: Hydraulic limitations imposed by crown placement determine final size and shape of Quercus rubra L. leaves. - Plant Cell Environ. 27: 357-365, 2004. 